\title{
The Political Strategy in Alleviating Poverty through Orwell's Animal Farm
}

\author{
Andi Farid Baharuddin ${ }^{1}$, Burhanuddin Arafah ${ }^{2}$ \\ \{baharuddinaf18f@student.unhas.ac.id ${ }^{1}$, burhan-arafah@unhas.ac.id² \\ Universitas Hasanuddin, Indonesia ${ }^{1,2}$
}

\begin{abstract}
This research aims at elaborating (1) the forms of poverty which existing in Animal Farm, and (2) will analyze the political strategy of the seven commandements which used to alleviate the poverty. In order to analyze this research, the researcher uses the sociology of literature theory, as the main approach and the poverty theory based on Marxism as the additional approach. Furthermore, the researcher uses qualitative methodology both for collecting data and analyzing data. In collecting data, the researcher separates three data, those are Primary Data which taken from the novel itself, Secondaray Data which quoted from the previous researcher, and Suppoting Data that can support the analysis quoted from books, journal, internet, cetera. The results of research found that in shaping poverty in Animal Farm novel, Mr. Jones has committed many undemocratic ways such as monopolizing the base structure and decreasing the animal consciousness. On the other hand, in alleviating poverty and prospering the animal society, Snowball, as the main character also does several strategies id east (1) Propaganda, (2) Rebellion, (3) Controlling the Base Structure, and (4) Education.
\end{abstract}

Keywords: Literature, Animal Farm Novel, Sociology of Literature, Poverty, Marxism

\section{Introduction}

Nowadays, many literary experts state that literature is frequently perceived as an educational media. It is due to its power in providing the moral value or cultural message can be transferred to the literary readers. Islam [1], one of the literary researchers, states that literature and education has a close relation in speaking about transferring knowledge and humanity through its text.

Based on the diversity of literary explanation above, the researchers perceive that these elucidations are in line with Horatius' thought when describing literature. Horatius, one of the great poet in Rome (65 SM-8 SM), in Teeuw [2] elaborates that the good literature must contain two discourses id est Dulce (entertaining) and Utile (educating and beneficial in social life) as its function in educating the readers. Therefore, by dropping these discourses in the literary works such as Prose, poetry, and drama the reader will be educated, entertained and could gain several messages behind its work.

However, in reality, people merely perceive literature as a media for entertaining the readers through literary work. It is because the writing style of the authors are extremely metaphoric, grandiloquent and unpractical for people. These are the reasons why literary text is frequently seen as the absurd reading, because the discourse in its work just presents about the romantical issues, horror, and comedy. 
Therefore, this research analyzes one of the great literary works that can expand the literary discourse to the socio-politics issues, humanity and poverty alleviation which benefit for the social life. The researcher does believe that elaborating the literary topic to the issues above, will be more substantial and educating for the readers.

Animal Farm Novel written by George Orwell, is the appropriate literary work which able to portray "poverty cause and its alleviation" in socio-politics issues. This novel was written in 1945 in England. Many literary researchers stated that this work is a satire literary work that attempts to criticize many rulers who led their countries badly such as Stalin (communism), Hitler (Nazi), Mussolini (fascism) and Cetera. Because of their political system and their political policy, most of their citizens were suffered, starving and even assassinated particularly for those who were in the bottom social class.

In contrast to the above social class, there were a few people who were welfare and honor due to the political policy released by those regimes that allow them to commit corruptions. Therefore, this novel attempts to criticize those phenomena by creating the satire work and characterizing the animal character which is extremely similar to the work (fable). For instance, in this novel, there is a figure who has the same character with Tsar character id est Mr. Jones.

Mr. Jones is basically an antagonist figure who does discrimination, corruption, and frequently torture the animals who want to disobey his desire. Mr. Jones is the manor farm who dominates all the production tools on the farm. He frequently gets drunk and almost never takes care of his farm [3]. Like the farmer, Mr. Jones does many bad things such as discrimination and corruption. He has power in monopolizing all the production tools, the natural resource and also able to force all animals to work. Furthermore, the result of production will be allocated in Mr. Jones place.

On the other hand, this novel also provides such a great lead character who leads the animal community namely Snowball. This character represents the good government in alleviating poverty. He is extremely benevolent, discipline, firm, and wise. In order to eliminate poverty in the animal community, one of his projects is educating all animals to read and write. By having a great education, all animals are expected to rebuild the community.

To make the poverty discourse in this research easy to be conceived, the researcher use Sociology of Literature Theory based on Lauranson and Swinghood Perspective [4]. According to their perspective in their book, in analtyzing the literary work the researcher first analyze the author's social background when expressing the notion. By understanding social circumstance of the author, the researcher could easily to find message behind the work.

\subsection{The Social Background when Orwell Writes The Animal Farm}

Animal Farm is one of the greatest literary works written by George Orwell which is assumed as a sharp satire to depict the social reality of totalitarian power. Definitely, Orwell would not be possible to express this novel without considering the social conditions where he expresses his literary work. Because, the social circumstance is the crucial factor of his life that had been influencing his idea in writing the novel. As has been known, Animal Farm novel was published in 1945 where second world war still occurred in some particular territory. At that moment, some countries which indicated as underdeveloped countries such as Philippine, Vietnam, Indonesia and most African area were still colonized by the power countries such as the United State of America, Soviet Union, England, German, etcetera. This condition causes the underdeveloped countries' natural resource are controlled by the power 
countries such as land territory, foods, oil, or even house. Therefore, there are numerous folks were starving and assassinated [5].

Besides, this novel also criticizes the dictatorial character leaderships who led their country badly. At that moment, many regimes frequently repress their citizen and running their system undemocratically. For instance, Hitler's dictatorial character could be objectified as an undemocratic ruler due to his political policy in committing mass murder and genocide to the Jewish people. This political policy set out by stating that Germany is the prestigious race and must be differentiated to the Jewish folks (lower-class). Consequently, most Jewish must be assassinated [6].

Another regime who had a strict character in leading his society is Joseph Stalin. When he led the soviet union, with the communist political system, he utilized all his political instrument in order to design the tyranny system. In undertaking his desire, he first forced the worker to assassinated most people who possessed the land. The reason is that the communist around the country must control the land and may gain the benefits from that. For the first, people agree about that policy. In fact, by dominating all the land as the people expect, did not guarantee that they will be wealth. People just felt hunger and assassinated by its system blindly.

Therefore, from the above case, Orwell attempts to characterize those corrupt regimes through Mr. Jones characteristics due to his role is similar to what the dictatorial regimes did. However, as a comparison to the Mr. Jones character, Orwell also provides a benevolent regime (Snowball) which is expected could have a political strategy in running the social farm democratically.

\section{Methodology}

In this point, the researchers explain the methodology which used to collect and analyze the data. in collecting and analyzing data, the researcher has divided some points such as Methodological Design, Method of Collecting Data, Method of Analyzing data, and Procedure of The Research.

\subsection{Methodological Design}

In doing this research, the researchers apply a methodology as a procedure used to approach the problem and solve it. To be known, Methodology is a study of method which constructs the general conception of the research. Research methodology consists of two parts; those are the quantitative research and the qualitative research. The quantitative research is a research that initially developed the study of natural phenomena and it reflects the philosophy that could be described according to some types of digital system such as statistics, mathematics, or computational techniques.

On the other hand, another part of the research methodology is the qualitative method. In analyzing this research, the researchers are using qualitative method to analyze literary work as the object of analysis. According to Ratna [7], the qualitative method gives more concern on the correlation between textual data and its existence. For instance, the analysis of literary works, the authors and their social circumstances. 
Based on the above description, the researcher could conclude that a qualitative method is a form of method process in doing research that based on its text which investigated the social phenomenon and human behavior problems.

\subsection{Method of Collecting Data}

Data is the most crucial element in doing a research. The researchers collect the data from the Animal Farm novel itself and several additional information through the library research. The Library research method allows the researchers to collect some data from various references by reading some textbooks, articles, thesis, research, and several critical writings that are relevant to this research. The researchers also do the note taking while finds data through the internet to collecting data.

In doing the library research, the researcher uses colored paper in collecting data and additional information which could strengthen this research. For the blue color paper, the researchers utilize it to note about political and ideological issue which correlated to this research. Furthermore, for the yellow color paper is used to note about sociology of literature theory and political strategy theory. Finally, the red color paper is used to write primary data which refers to the novel.

By doing the library research, the researchers have classified the data into three parts, those are Primary data, Secondary data and Supporting data. The primary data are:

\subsubsection{Primary Data}

As has been mentioned earlier that primary data is the main data in this research. The primary data hold the position as the focus of the study. Furthermore, The primary data in this thesis is the Animal Farm written by George Orwell.

\subsubsection{Secondary Data}

Secondary data is data which amplify about the previous explanation which related to this research. These secondary data came from the books and previous research related to the issues of Leadership and Poverty alleviation.

\subsubsection{Supporting Data}

Supporting data is the data supporting the analysis. The supporting data came from several articles that the author got, from the books, internet and somewhere else related to the issues.

\subsection{Method of Analyzing Data}

In analyzing the data, the researchers are using the Sociology of Literature approach to understand the structure of the work and the humanity facts especially about social class contradiction and poverty alleviation in Orwell's Animal Farm novel. Therefore, in analyzing the above social cases detaily, the researchers are using marxist perspective as the additional approach. 


\section{Findings and Discussion}

This point is separated into two part of the explanation. The first part is finding of the research which attempts to describe the relation between the poverty alleviaiton theory and the finding data. Furthermore, the second part is the discussion of the findings.

\subsection{Findings}

The researchers provide several data related to the Animal Farm novel as the object of the researchers' analysis id est what are the causes of poverty exist in Animal Farm? and how do the characters alleviate the poverty?

\subsubsection{What Cause of Poverty Exist in Animal Farm}

Theoritically, in Marxist perspective, people's character had been formed by the cultural system which could not be separated from the Base Structure acquisition. the Base Structure is the system of life that can encourage people to full fill their life necessities. It consists of Productive Source (natural resource) and Productive Tool [8].

Those who have the political power in controlling the base structure are classified as the upper class (bourgeois) in society. This cluster has a political opportunity in running the system which stands for their interest. On the other hand, for those who are lack of ability in controlling and monopolizing the Base Structure are assumed as the working class [9].

Furthermore, In order to strengthen the upper class' political power, they must construct and regulate the society exampli gratia dogmatizing people with religion culture, literature, art et cetera (this part is called Super Structure). Super Structure is a further structure based on the base structure. Super Structure consists of politics, law, literature, art, culture, and education.

In Animal Farm novel, there are numerous social portraits that depict about poverty and its cause. This thing occurs when Mr. Jones as the manor farm, posses and rules the society around that territory. He does discrimination, corruption, and frequently torture his working animals that attempts to disobey his desire. Moreover, as the ruler, he never takes care of his animal and rarely supplies for the animal's woof.

This phenomena could be followed through the Old Major 1 narration when he gathers all animals to retell what he has experienced since living on Mr. Jones farm. Old Major is basically told by his ancestor that all animal society were hunger slaughter, and forced to work on the farm the source production (Base Structure) is taken and monopolized by a single ruler namely Mr. Jones. Old Major narrates as follow:

Data 1: "why then do we continue in this miserable condition? Because nearly the whole of the produce of our labours is stolen from us by human beings" [3].

The above data shows that the cause of poverty exists in this novel due to the base structure and the result of production is controlled and possessed by the animal's lord (human being). Therefore, the effect of this case makes the animals are objectified as a working class and even commodity. They do not have a right to speak nor disobey Mr. Jones' order. They

${ }^{1}$ Old Major is one of characters in the Animal Farm novel who is benevolent, a great preacher, and majestic-looking pig. His real name was Wilingdon Beauty, but most animals in the farm recognize him as the Old Major. 
are frequently forced to worked and gives everything that the animals have to Mr. Jones. They are merely given less food in order to continue their breath and work.

Data 2: "Now, comrades, ,..., Lets face it, our lives are miserable, laborious and short. We are born, we are given just so much food as will keep the breath in our bodies and those of us who are capable of it are forced to work to the last atom of our strength,..." [3].

Consquently, because the source production (base structure) acquisition forms and classifies the social cluster, thereby it discriminates all the society around the farm both for human being (the upper class) and animals (the working class). The discrimanation scheme could be perceieved through Old Major statment,

Data 3: "Man (the upper class who have monopolized the base structure) is the only creature that consumes without producing. He does not give a milk, he does not lay eggs, he is too week to pull the plough, he cannot run fast to catch rabbits. Yet, he is lord of all animals" [3].

From the above quotation, it could be presumed that a ruler definately has the political power in forcing the animals to work for the ruler interest and getting benefits from it. Because the productive source has been monopolized by human beings. Nevertheless, the Old Major attempts to motivate and educate the animals ro gain their rights to be the freedom workers.

Based on the novel, the researchers perceive that there are several political strategies, in alleviating poeverty, narrated by Orwell. These strategies are described in the bellow point.

\subsubsection{How Do Characters Alleviate Poverty}

This point provides the political strategy discourses used to alleviate poverty in the Animal Farm. Based on marxist theory in Prawironegoro [10], in alleviating poverty there are several political steps/strategies that should be committed. Those political strategies are, 1) Propaganda, 2) Rebellion, 3) Controlling the base structure, 4) and Education.

\subsubsection{Propaganda}

Theoritcally, the word propaganda comes from Latin, Propagare, which means dissemination [11]. This word refers to the spreading of the information which must be received by people who listen or read the propaganda. Propaganda could be one of the critical instrument in transferring someone desires both in politics-economy and socio-culture.

In the Animal Farm novel, the figure who is honored to transfer and spread the information is called Old Major. He frequently states that the manor's cupidity designs this miserable condition. Animals have been repressed, tortured, and forced to work for the Jones desire. Therefore, after retelling the truth of Mr. Jones cupidity, he furthermore propagandizes the animals to fight against the ruler, he states as follow:

Data 4: "why, work night and day, body and soul, for the overthrow of the human race! That is my message to you, comrades: Rebellion I do not know when 
Rebellion will come. ,... but I know, as surely as I see this straw beneath my feet, that sooner or later justice will be done " [3].

This statement is objectified as propaganda that might triggers the animals to fight and commit rebellion. He subsequently continues his speech that human beings and animals cannot be unified in society because they both have a different interest. For human beings, they desire to be classified as the upper class, on the other hand the animals are classified as the marginal class. Old Major describes:

Data 5: "Never listen when they tell you that Man and the animals have a common interest, ..., it is all lies. Man serves the interests of no creature except himself. And among us animals let there be perfect unity, perfect comradeship in the struggle. All men are enemies. All animals are comrades" [3].

Based on the above case, it could be perceived that the human system designs a social cluster between the upper class (human beings) and the working class (animals) due to the base structure domination. Therefore, the Old Major propagandizes that as long as human beings monopolize the base structure and reature resource, then the discrimination will always exist in real life.

\subsubsection{Rebellion}

Rebellion is the second strategy in reaching freedom. After listening to the old major's speech, most animals are encouraged to commit a rebellion and prosper their cluster. Most animals are motivated and inspired to rebel the social sytem which discraminated them. One of the characters who has an ability in orginizing the working class rebelion is Snowball. This character represents a wise leadership, benevolent, and discipline.

The rebeleion scheme in this novel occured when Mr. Jones does not take care of his animals. Mr. Jones does not feed the animal neither when the animals are working in the morning nor when the feeding time. This incident makes the animals are hunger. Orwell narrated how rebellion occured in the novel:

Data 6: "When Mr. Jones got back he immediately went to sleep on the drawingroom sofa with the News of the World over his face, so that when evening came the animals were still unfed. At last they could stand it no longer. One of the cows broke in the door of the store-shed with her horn and all the animals began to help themselves from the bins. It was just then that Mr. Jones woke up. The next moment he and his four men were in the store-shed with whips in their hands, lashing out in all directions. This was more than the hungry animals could bear. With one accord, though nothing of the kind had been planned beforehand, they flung themselves upon their tormentors. Jones and his men suddenly found themselves being butted and kicked from all sides" [3].

The above data shows how anger animals in rebelling Mr. Jones due to his arrogance in caring the animals. Mr. Jones never realizes that the animals might demand their rights and behave like they are not used to be. Besides, this condition could not be controlled because all the animals desire is to dislodge Mr. Jones dictatorship from the farm. Orwell portrays: 
Data 7: "The situation was quite out of their (Mr. Jones and his colleagues) control. They had never seen animals behave like this before, and this sudden uprising of creatures whom they chose, frightened them almost out of their wits. After only a moment or two they gave up trying to defend themselves and took to their heels. A minute later all five of them were in full flight down the cart track that led to the main road, with the animals pursuing them in triumph" [3].

Based on the above phenomena, the researchers perceive that this situation is indicated as the rebellion of animals in demanding their rights as a society of the animals. The researcher furthermore observes that after gaining their economic power, the animals point Snowball as the leader of the animal society and expect that snowball could lead the animals equally and control the base structure which stand for the animal's interest.

\subsubsection{Re-controlling The Base Structure}

After committing the rebellion and expelling Jones from the farm, they then realize that the manor farm is theirs. Snowball, with all animals, attempts to control all production source (base structure) equally to eliminate poverty around them and prosper each other.

On the first day of their revolution, Snowball, who is admired as a disciplined leader, states that all animals will work hard together as usual. Nevertheless, the result of the production are not allocated to Mr. Jones place anymore. Yet, those are allocated for all animals equally. Snowball states;

Data 8: “..., 'Comrades, it is half past six and we have a long day before us. Today, we begin the hay harvest' said Snowball. ,... the animals were happy as they had never conceived it possible to be. Every mouthful of food was an acute positive pleasure, now that it was truly their own food. Produced by themselves and for themselves ...," [3].

This above statement is the impact of controlling the base structure, which stands for their interest. Due to, all production is handled by them, and automatically the result of all production belong to them. In addition to the above case, since animals control the base structure in the farm, they subsequently work according to their capacity. No animals steal, no animals grumble over their rations, the quarreling and biting and jealousy which had been a common feature of life in the old days had almost disappeared.

Therefore, the researchers perceive that one of the brilliant approaches in alleviating poverty is controlling the base structure that stands for the majority interest and not for a minority cluster. The impact of applying this thing could prosper the society from being famished to be welfare.

In addition to the above explanation, by controlling the base structure for themselves, there will be no animals consume food or beverage more than any others. Due to the result of the production will be allocated equally. Furthermore, they also could develop their ability in operating the tools of production to produce many foods and beverage.

Data 9: “..., Snowball also busied himself with organizing the other animals into what he called Animal Committees. He was indefatigable at this. He formed the eggs production committee for the hen, the clean tails league for the cows, ..., the 
Whiter Wool Movement for the sheep, and various other, besides instituting classes in reading and writing" [3].

These things could be achieved by dominating the base structure collectively. Animals could work based on their capacity, they are not tortured by any human beings, they have more leisure time rather than being carried by Jones, they have an ability and feel free to operate all the production, and last they are able to do whatever they desire to do because the farm is theirs.

\subsubsection{Education}

Education is the final strategy in alleviating poverty. Education is a crucial element because it maintains the majority interest in dominating the base structure. Besides, education could be conceived as the superstructure, which must be doctrinized to the people's consciousness. Education should stand for the existence of the lower and working class democratically.

After rebelling Jones and being able to control the base structure, Snowball furthermore designs an animal principle that could bind their fraternity. Snowball, the best writer in animal society, deletes the sentence of Manor Farm and repaints Animal Farm and its faith, Orwell situates it when Snowball attempts to amplify the Animal Farm principle as a curicculum for the animal education:

Data 10: "Then Snowball (for it was Snowball who was best at writing took a brush between the two knuckles of his rotter, painted out Manor Farm from the top bar of the gate and its place painted Animal Farm. ,... of the past three months the pig had succeeded in reducing the principle of animalism to Seven Commandments. ... The commandments were written on the tarred wall in great white letters that could be read thirty yards away;

a. Whatever goes upon two legs is an enemy.

b. Whatever goes upon four legs or has wings, is a friend.

c. No animal shall wear clothes.

d. No animal shall sleep in a bed.

e. No animal shall drink alcohol.

f. No animal shall kill any other animal.

g. All animals are equal" [3].

Based on the above principles, it could be seen that all animals must respect any other animals. These principles are transferred to every animal on the farm. Snowball, as a leader, teaches the animals how to read and write. Snowball does believe, by having a lot of knowledge, the animals could be smarter than any other human, Orwell narrates this situation;

Data 11: "The reading and writing classes, however, were a great success. By the autumn almost every animal on the farm was literate in some degree. As for the pigs, they could already read and write perfectly. The dog learned to read fairly well" [3]. 
The above data indicates how crucial education is. Therefore, the researchers perceive that obtaining a lot of knowledge guides the animals to operate the tools in producing their needs.

\subsection{Discussion}

The researchers have stated that the Animal Farm novel is a satire work that attempts to portray strict regimes who have run the system undemocratically. At that time where the second world war occurs, the author of this novel attempts to criticize the figure of those strict regimes and personified them to Mr. Jones character. Therefore, to analyze it profoundly using Sociology of Literature theory, the researcher will discuss the finding data to the social experience of the author.

To be known, one of those regimes who have indicated as undemocratic regime is Nikolai known as Nicholas 2. When Nikolai 2 leads the Russian, he has political power in dominating all of the natural and human resources, which objectified as the base structure. All of the results are consigned to him and his family in the kingdom.

Besides, he is also presumed as an inconsiderate because he just releases a public policy for intimidating his opposites such as Lenin, Stalin, Plekhanov, and many people who have a different interest. These things cause all people from the lower and working class commit a rebellion [12]. Therefore, Nikolai Tsar is objectified as Mr. Jones due to a similarity character in running the system unequally and monopolizing the base structure. Montofiore states in his book when Nikolai is going to be rebelled;

Data 12: “, ... 'Revive' said Lenin in an article. 'Our red blood boils with the fire of strength!... '. Lenin continues that 'Revolution rose again' [12].

From the above quotation, it could be perceived that Lenin attempts to propagandize the society and his comrades to fight against Tsar's power. Because they have been repressed, intimidated, and were starving for a long time. Furthermore, the discourse of the political strategy in alleviating poverty could be seen to Snowball due to a simlar character with Lenin. One of the essential strategies is education after controlling the base structure.

This portray is quite similar to Lenin's character. Lenin always educates his partners with political ideology. Montefiore describes that Lenin frequently spent his time writing and teaching his comrades for preparing a revolution against Nikolai 2 [12]. As a result of the discussion point, the researchers perceive that analyzing the literary work using sociology of literature approach could enhance numerous data both in the intrinsic element of the work and its extrinsic of the work (Social background of the author). Besides, the researcher also could correlate both data scientifically into this research.

\section{Conclusion}

The researchers conclude that poverty is designed by the greediness of Mr. Jones when dominating farm as the base structure (refers to Marxism thought). If it is correlated in a social context, Mr. Jones could be presumed as a Nikolai 2 or Czar (most Russians called Tzar), as a king who dominates the natural and human resource. 
This causes the result of production is consigned for Mr. Jones. Besides, when Mr. Jones leads the farm, he never take cares of his animals well. Mr Jones frequently persecutes all animals if they do not work well. Based on this situation, there is an Old Major who desires to increase animals consciousness in rebelling the dictatorship of Mr. Jones. Subsequently, this spirit is continued by Snowball in expelling Mr. Jones out of Farm.

After reaching freedom, Snowball furthermore plains a political strategy in prospering the animals exampli gratia Propagandize the animals society (first transferred by Old Major), Rebellion, Re-controlling The Base Structure, and educating all animals. Snowball believes, by educating all animals, they can read, write, and operate all the production tool.

\section{References}

[1] A. F. Islam, Introduction to Literature. Yogyakarta: Beranda Publishing Book, 2016.

[2] A. Teeuw, "Sastra dan ilmu sastra: Pengantar teori sastra," Pustaka Jaya, 1984.

[3] G. Orwell, “Animal Farm.” London, Penguin, 1951.

[4] D. Laurenson and A. Swingewood, The sociology of literature. Paladin, 1972.

[5] T. Malaka, Aksi Massa. Yogyakarta: Narasi, 2013.

[6] E. Wiesel, Night Kesaksian Tentang Holocaust Esensi. Erlangga, 2006.

[7] K. R. Nyoman, “Teori, Metode, dan Teknik Penelitian Sastra," Yogyakarta: Pustaka Pelajar, 2004.

[8] M. Karl, "Capital.” Progress Publishers, Moscow, 1959.

[9] A. F. Baharuddin, Tombak Merah Sehimpun Tulisan Bernada Gelora. Probolinggo: Anlitera Publisher, 2019.

[10] D. Prawironegoro, "Karl Marx: Ekonomi Politik dan Aksi Revolusi," Jakarta Nusant. Consult., 2012.

[11] S. Wasono, Sastra Propaganda. Jakarta: Wedetama Widya Sastra Publisher, 2007.

[12] S. S. Montofiore, Stalin Muda. Ciputat: Pustaka Alvabety Publisher, 2012. 